Maulana Danar Maaliki $\mathrm{H}^{1}$ Ryan Anggara ${ }^{2}$ Yumna Nafisah ${ }^{3}$ Chafit Ulya $^{4}$

\section{ANALISIS KESALAHAN BERBAHASA PADA TATARAN MORFOLOFI, EBI, DAN SINTAKSIS BUKU TEKS SOSIOLOGI KELAS X SMA}

\begin{abstract}
Abstrak
Penelitian ini berjudul "Analisis Kesalahan Berbahasa Pada Tataran Morfologi, EBI, dan Sintaksis Buku Teks Sosiologi Kelas X SMA". Tujuan utama pada artikel ini adalah analisis kesalahan dan pembenaran kaidah berbahasa pada tataran morfologi, EBI, dan sintaksis pada buku teks Sosiologi kelas X SMA karya Ruswanto. Metode penelitian ini menggunakan metode kualitatif deskriptif. Teknik pengumpulan data dalam penelitian ini menggunakan metode bacacatat, yaitu suatu metode pengumpulan data dengan cara membaca bahan ajar. Kesalahan kaidah penulisan yang dianalisis pada penelitian ini adalah kesalahan morfologi, kesalahan Ejaan Bahasa Indonesia (EBI), dan kesalahan sintaksis. Aspek kesalahan morfologi yang dianalisis pada penelitian ini adalah kesalahan penggunaan prefiks. Analisis kesalahan penulisan pada tataran Ejaan Bahasa Indonesia (EBI) dalam penelitian ini adalah kesalahan pemakaian tanda baca. Kesalahan sintaksis yang ditemukan penelitian ini berupa kesalahan struktur kalimat efektif. Sampel yang digunakan pada penelitian ini merupakan buku teks sosiologi kelas $\mathrm{X}$ SMA KD 3.1 dan 4.1 yang diambil dari buku karya Ruswanto.
\end{abstract}

Kata Kunci: Kesalahan Berbahasa, Buku Teks Sosiologi, Morfologi, EBI, Sintaksis

\begin{abstract}
The study was titled " Analisis Kesalahan Berbahasa Pada Tataran Morfologi, EBI, dan Sintaksis Buku Teks Sosiologi Kelas X SMA ". The main purpose of this article is the analysis of errors and justification of language rules at the morphological, EBI, and syntax levels in Ruswanto's class X SMA Sociology textbook. This research method uses descriptive qualitative method. Data collection techniques in this research use a method of read-note, which is a method of data collection by reading teaching materials. The writing rule errors analyzed in this study were morphological errors, Indonesian Spelling (EBI) errors, and syntax errors. The aspect of morphological errors analyzed in this study was the misusing of prefixes. Analysis of writing errors at the Indonesian Spelling Level (EBI) in this study is an error in the use of punctuation. Syntax errors found this research in the form of effective sentence structure errors. The samples used in this study are sociology textbooks class X SMA KD 3.1 and 4.1 taken from the book by Ruswanto.
\end{abstract}

Keywords: Language Errors, Sociological textbooks, morphology, EBI, Syntax.

\footnotetext{
${ }^{123}$ Pendidikan Bahasa Indonesia, Fakultas Keguruan dan Ilmu Pendidikan, Universitas Sebelas Maret

${ }^{1}$ Alamat email maulanadanarmh@student.uns.ac.id

2 Alamat email ryananggara80@ student.uns.ac.id

3 Alamat email yumnanafisah29@student.uns.ac.id

${ }^{4}$ Alamat email chafit@staff.uns.ac.id
} 


\section{PENDAHULUAN}

Mengkaji mengenai bahasa dan segala seluk beluk tentannya termasuk kesalahan yang dilakukan maka akan lebih baik jika mempelajari mengenai bahasa itu sendiri. Pengertian dari bahasa itu sendiri adalah rangkaian bunyi yang mempunyai makna tertentu, rangkaian dalam bunyi yang secara umum masyarakat ketahui sebagai kata, melambangkan dan menjelaskan mengenai suatu konsep. Dalam penggunanya bahasa mengalami perkembangan, tidak hanya memiliki fungsi alat komunikasi tetapi juga berperan sebagai media dan alat untuk berfikir.

Bahasa merupakan suatu alat untuk berpikir, berlogika serta untuk belajar, bahasa berguna bagi kita untuk memungkinkan berpikir secara abstrak pandangan tersebut dikemukakan oleh Kosasih (2011:2). Bahasa adalah salah satu bentuk yang digunakan untuk mempersatukan bangsa, bangsa dengan beragam bahasa yang ada. Seperti bangsa Indonesia ini yang memiliki ribuan pulau yang berada berbagai macam wilayah yang tersebar di dalamnya. Dengan demikian Indonesia memiliki ragam variasi bahasa. Bahasa Indonesia dalam penggunaannya di kehidupan masyarakat Indonesia sendiri memiliki tempat dan kegunaan sebagai bahasa nasional. Bahasa Indonesia juga merupakan bahasa negara. Pemerintah meningkatkan fungsi bahasa Indonesia sebagai bahasa internasional Sebagai bentuk pensakralan bahasa Indonesia. Hal tersebut sesuai dengan UU No. 24 Tahun 2009 tentang bendera, bahasa, lambang negara, dan lagu kebangsaan.

Kondisi yang terjadi dalam masyarakat yang sekarang ini marak terjadi adalah menggunakan bahasa Indonesia tidak sesuai pedoman. Pedoman dalam penggunaan bahasa tersebut merupakan penggunaan sesuai dengan konteks penggunaan bahasa. Banyak masyarakat yang mencampur adukan penggunaan bahasa baik itu bahasa lisan maupun bahasa tulis. Kesalahan dalam berbahasa Indonesia salah satunya dapat terjadi dalam tataran morfologi dan sintaksis.

Menurut pernyataan dari Chaer (2008:3) dalam kajian ilmu disiplin morfologi memiliki makna mengkaji mengenai berbagai bentuk dan macam pembuatan kata. Ketika mempelajari bahasa yang ada dan pengandaian sebagai alat komunikasi akan sangat erat hubungannya dengan kajian morfologi. Kajian dalam bidang morfologi memiliki makna bahwa mempelajari bagian dari struktur bahasa mencakup penggunaan kata dan bagian-bagian kata,atau morfem. Ilmu disiplin morfologi menjadi krusial peranannya dalam pengkajian dan pembelajaran seluk beluk bahasa. Hal itu karena peran penting disiplin ilmu morfologi dalam pembentukan morfem dan kata sebagai awal dan pondasi pembentukan frasa, klausa, kalimat, paragraf, serta wacana. Suatu pernyataan mengatakan bahwa bahasa merupakan alat dan memiliki fungsi untuk menyampaikan pesan kepada pendengar atau pembaca.

Bahasa tulis banyak digunakan dalam kehidupan dan kegiatan akademis. Penerapan kemampuan menulis ini harus berdasarkan pada kaidah yang diterapkan dan yang ada di Indonesia. Penulisan pada kehidupan akademis sangat mempengaruhi mutu dan penilaian orang terhadap instansi atau pribadi tersebut. Oleh karena itu penerapan kaidah kebahasaan harus benar-benar diawasi. Kaidah kebahasaan memang menjadi dasar dalam penulisan artikel yang ada pada dunia akademis. Walaupun demikian, masih banyak ditemukan kesalahan-kesalahan dan penyimpangan yang digunakan dalam berbahasa dalam penulisan artikel. Tidak hanya dalam artikel tetapi penulisan dalam dunia akademis juga diterapkan dalam sumber-sumber informasi seperti buku teks, dan sumber ilmu lain.

Kesalahan-kesalahan tersebut sering ditemukan dalam bentuk tataran ejaan, tataran fonologi, tataran sintaksis, tataran semantik, serta tataran morfologis. Salah satu tataran kesalahan berbahasa adalah kesalahan dalam tataran semantik atau ambiguitas makna(Jati, 2019). Semantik dapat diartikan bahwa pada umumnya semantik merupakan sebuah studi tentang makna(Rogers \& McClelland, 2018). Menurut Pateda (1989: 62) daerah kesalahan semantik berkaitan dengan kurang tepatnya penggunaan kata dalam bertutur dan pemahaman makna kata. Kesalahan semantik yang terdapat dalam penulisan sebagian besar terjadi karena penggunaan diksi yang kurang tepat sehingga menimbulkan ambiguitas makna.

Kesalahan yang sering terjadi salah satunya dalam ragam tulis. Setyawati (2010) mengemukakan dikaji dalam ranah pemakaian bahasa pada ragam bahasa tulis (kemampuan 
menulis) pemakaian dan penerapan bagian bahasanya condoh dan banyak yang tidak lengkap. Oleh karena itu, dalam penyampaiannya jika pesan dan maksud yang ingin dikirim atau disampaikan kepada pembaca diterima dengan baik, maka unsur bahanya diwajibkan lengkap. Keterampilan berbahasa yang digunakan dalam kehidupan sehari-hari dapat berbagai macam. Keterampilan berbahasa yang digunakan salah satunya adalah kemampuan dalam ragam tulis. Keterampilan bahasa ragam tulis termasuk kemampuan yang cukup penting. Kemampuan menulis berarti bahwa mengungkapkan pikiran, perasaan pendapat, dan gagasan serta ide yang ada dan dimiliki dan dituangkan melalui hasil menulis. Keterampilan berberbahasa menulis memerlukan semua keterampilan berbahasa yang diwajibkan untuk dikuasai dan dimaksimalkan secara baik untuk memperoleh hasil yang diinginkan dengan baik (Sardila, 2016).

Keterampilan menulis memiliki potensi yang sangat besar terdapat kesalahan didalamnya. Kesalahan dalam keterampilan menulis biasanya terdapat pada kesalahan ejaan. Selain itu analisis mengenai keterampilan menulis adalah dalam bidang morfologi. Salah satu hasil dalam karya tulis buku teks. Penggunaan buku teks dalam dunia pendidikan sangat krusial. Karena buku teks digunakan sebagai media yang guru atau pendidik gunakan. Banyak guru bahkan menggunakan buku teks sebagai pedoman utama dalam menyampaikan pembelajaran.

Penggunaan buku teks dalam setiap pelajaran yang dilakukan di sekolah merupakan salah satu cara pemaksimalan materi yang telah disusun dalam buku teks. Buku teks dalam pelajaran merupakan sumber dan media dalam pengajaran yang sangat krusial. Substansi yang ada dalam buku teks telah disusun dan dirancang secara khusus untuk kegiatan belajar mengajar siswa dalam semua jenjang. Pada hal yang demikian maka sangat penting jika menjaga mutu dan muatan dalam buku teks.

Berlandaskan kepada permendiknas No. 2 Tahun 2008 yang menjelaskan mengenai penggunaan dan pedoman buku teks, maka tidak salah lagi jika penjaminan mutu dalam buku teks harus benar-benar dilakukan, Fungsi buku teks secara umum merupakan media atau sarana yang krusial; dan dinilai ampuh untuk menyediakan pemenuhan kegiatan dan belajar mengajar. Sebagai media pengajaran, dalam kehidupan belajar mengajar penggunaan buku teks sebagai sumber pelajaran merupakan pilihan strategis. Artikel ini berusaha untuk melakukan analisis kesalahan tataran morfologi dan sintaksis yang terdapat dalam buku teks. Besar harapan peneliti artikel ini dapat berguna dalam peninjauan, dan perbaikan dalam pembuatan buku teks yang digunakan sangat krusial dalam pendidikan.

\section{METODE}

Sumber data penelitian ini adalah buku teks sosiologi kelas X SMA dengan mengambil KD 3.1 dan 4.1 untuk dianalisis. Data penelitian ini berupa kesalahan morfologi dan kesalahan Ejaan Bahasa Indonesia (EBI). Teknik pengumpulan data dalam penelitian ini menggunakan metode baca-catat, yaitu suatu metode pengumpulan data dengan cara membaca bahan ajar. Buku teks yang dibaca merupakan buku teks sosiologi kelas X SMA KD 3.1 dan 4.1 karya Ruswanto. Setelah itu, dilanjutkan klasifikasi data berdasarkan prinsip-prinsip tertentu yang mengarah pada kepentingan analisis dan pencapaian tujuan penelitian (Subroto, 2007: 99). Penelitian ini menggunakan metode deskriptif kualitatif.

\section{HASIL DAN PEMBAHASAN}

Kesalahan kaidah penulisan yang dianalisis pada penelitian ini adalah kesalahan morfologi, kesalahan Ejaan Bahasa Indonesia (EBI), dan kesalahan sintaksis. Aspek kesalahan morfologi yang dianalisis pada penelitian ini adalah kesalahan penggunaan prefiks. Analisis kesalahan penulisan pada tataran Ejaan Bahasa Indonesia (EBI) dalam penelitian ini adalah kesalahan pemakaian tanda baca. Kesalahan sintaksis yang ditemukan penelitian ini berupa kesalahan struktur kalimat efektif. Sampel yang digunakan pada penelitian ini merupakan buku teks sosiologi kelas X SMA KD 3.1 dan 4.1 yang diambil dari buku karya Ruswanto. 
1. Kesalahan Penulisan Tataran Morfologi

Analisis kesalahan penulisan pada tataran morfologi bahan ajar sosiologi KD 3.1 dan 4.1 karya Ruswanto ditemukan sebanyak satu kesalahan, yaitu penggunaan prefiks me(N). kesalahan tersebut ditemukan pada kalimat berikut yang terdapat pada halaman 3 .

"Objek material sosiologi adalah kehidupan sosial, gejala-gejala, dan proses hubungan antarmanusia yang mempengaruhi kesatuan hidup manusia itu sendiri”.

Kata mempengaruhi merupakan hasil dari proses afiksasi antara morf me(N)-i dan morfem pengaruh. Hasil proses afiksasi me(N)-i dan pengaruh adalah sebagai berikut.

$$
\operatorname{me}(\mathrm{N})+\text { pengaruh }-\mathrm{i}=\text { memengaruhi }
$$

Berdasarkan kaidah penulisan EBI, huruf p pada morfem pengaruh menjadi luluh karena didahului morf me(N) dan menghasilkan alomorf [mem-]. Hal serupa juga terjadi pada morfem yang didahului huruf $\mathrm{p}$ lainnya, seperti kata memisah merupakan bentuk afiksasi dari $[\mathrm{me}(\mathrm{N})+$ pisah], kata memanah merupakan bentuk afiksasi dari $[\mathrm{me}(\mathrm{N})+$ panah], dan sebagainya. Hal ini sejalan dengan KBBI yang menyebutkan bahwa kata mempengaruhi merupakan bentuk tidak baku dari kata memengaruhi. Maka pembenaran bentuk kesalahan tersebut sebagai berikut.

"Objek material sosiologi adalah kehidupan sosial, gejala-gejala, dan proses hubungan antarmanusia yang memengaruhi kesatuan hidup manusia itu sendiri”.

2. Kesalahan Penulisan Tataran Ejaan

Analisis kesalahan penulisan sesuai kaidah EBI pada bahan ajar sosiologi KD 3.1 dan 4.1 karya Ruswanto ditemukan sebanyak 3 kesalahan. Analisis kesalahan pemakaian tanda baca yang ditemukan pada bahan ajar sosiologi KD 3.1 dan 4.1 karya Ruswanto adalah penggunaan tanda koma (,). Kesalahan tersebut ditemukan pada kalimat berikut yang ditemukan pada halaman 11, 16, dan 19.

(11) "Sosiologi, merupakan sifat-sifat atau ciri-ciri yang timbul dari kehidupan masyarakat dan relasi sosial yang dilembagakan".

(16) "Ia membagi sosiologi ke dalam dua bagian besar, yaitu statika sosial yang mewakili stabilitas atau kemantapan, dan dinamika sosial yang mewakili perubahan".

(19) "Tujuan tersebut, yaitu suatu hasil akhir atas suatu tindakan dan perilaku seseorang yang harus dicapai melalui perubahan maupun dengan cara mempertahankan suatu keadaan yang sudah bagus".

Kesalahan pemakaian tanda baca yang didapat pada kalimat (11), (16), (19) adalah pemakaian tanda koma di ketiga kalimat tersebut. Kata sosiologi, kemantapan, dan tersebut tidak termasuk karakteristik kata yang membutuhkan pemakaian tanda koma. Penempatan koma pada ketiga kata tersebut tidak sesuai dengan aturan PUEBI. 
Kata merupakan yang terletak setelah kata sosiologi memiliki makna untuk mendefinisikan arti sosiologi, sehingga adanya tanda koma sebelum kata merupakan tidak diperlukan, karena klausa yang terletak setelah kata sosiologi tidak menunjukkan keterangan tambahan atau keterangan aposisi. Sama halnya dengan kata merupakan, peletakkan tanda koma sebelum kata yaitu tidak diperlukan. Kata yaitu merupakan kata hubung, akan tetapi bukan termasuk kata hubung dalam kalimat majemuk setara. Kata yaitu digunakan untuk memerinci keterangan dari frasa "tujuan tersebut". Kalimat (16) merupakan salah satu contoh kalimat yang menunjukkan unsur dalam suatu pemerincian, akan tetapi kalimat tersebut hanya menunjukkan dua unsur dalam suatu pemerincian. Tanda koma diletakkan sebelum kata dan, apabila unsur dalam suatu pemerincian terdiri dari tiga unsur atau lebih. Maka pembenaran dari bentuk-bentuk kesalahan tersebut sebagai berikut.

(11) "Sosiologi merupakan sifat-sifat atau ciri-ciri yang timbul dari kehidupan masyarakat dan relasi sosial yang dilembagakan".

(16) "Ia membagi sosiologi ke dalam dua bagian besar, yaitu statika sosial yang mewakili stabilitas atau kemantapan dan dinamika sosial yang mewakili perubahan".

(19) "Tujuan tersebut yaitu suatu hasil akhir atas suatu tindakan dan perilaku seseorang yang harus dicapai melalui perubahan maupun dengan cara mempertahankan suatu keadaan yang sudah bagus".

3. Kesalahan Penulisan Tataran Sintaksis

Analisis kesalahan struktur kalimat efektif pada bahan ajar sosiologi KD 3.1 dan 4.1 karya Ruswanto ditemukan sebanyak 5 kesalahan. Analisis kesalahan struktur kalimat yang ditemukan pada bahan ajar sosiologi KD 3.1 dan 4.1 karya Ruswanto adalah penggunaan kata yang berlebihan, sehingga menjadikan suatu kalimat tidak efektif. Kesalahan tersebut ditemukan pada kalimat berikut yang ditemukan pada halaman 2, 6, 7, 11, dan 18.

(2) "Sosiologi atau ilmu masyarakat ialah ilmu yang mempelajari struktur sosial dan proses-proses sosial, termasuk perubahan-perubahan sosial".

(6)"berusaha mengenali persamaan-persamaan dan perbedaan-perbedaan sampai kepada generalisasi".

(7) "memberikan uraian tentang variasi bentuk-bentuk sosial dan mencatat asalusul serta perkembangan manusia dengan adat-istiadatnya, mencakup dimensi waktu".

(11)“sosiologi merupakan ilmu-ilmu sosial yang paling luas dasar-dasarnya”.

(18) "Elemen-elemen sosial itu terdiri atas tindakan-tindakan sosial yang dilakukan individu-individu yang berinteraksi satu dengan yang lainnya". 
Karakteristik-karakteristik kalimat efektif meliputi kelugasan, ketepatan, kejelasan, kehematan, dan kesejajaran. Frasa "struktur sosial dan proses-proses sosial" pada kalimat (2) menunjukkan adanya ketidaklugasan yang terkandung dalam kalimat tersebut. Kata sosial pada frasa "struktur sosial dan proses-proses sosial" merupakan satu pokok, sehingga tidak diperlukan adanya pengulangan kata sosial dalam satu frasa. Penggunaan kata ulang (nomina dengan makna banyak) secara berturut-turut di antara kata hubung "dan" merupakan suatu pemborosan dalam sebuah kalimat. Seperti halnya pada kalimat (6) frasa "persamaan-persamaan" dan "perbedaan-perbedaan" yang menyatakan nomina dengan makna "banyak".

Kata "variasi" pada kalimat (7) memiliki makna bentuk (rupa) yang lain; yang berbeda bentuk (rupa) dalam entri KBBI. Kata variasi memiliki arti jenis-jenis dalam entri tesaurus. Frasa bentuk-bentuk merupakan reduplikasi dengan makna jamak atau banyak. Maka dapat disimpulkan bahwa setelah kata variasi tidak diperlukan adanya reduplikasi untuk memenuhi karakteristik kalimat efektif dalam bentuk penghematan dan kelugasan. Pada kalimat (7) terdapat kata "paling"yang menunjukkan sifat superlatif. Dalam entri KBBI, superlatif memiliki arti tingkat perbandingan yang teratas (bentuk kata yang menyatakan paling, yaitu ter-). Frasa "Ilmu-ilmu sosial" yang mendahului frasa "yang paling luas" menunjukkan makna jamak, sehingga frasa tersebut berbanding terbalik dengan frasa "ÿang paling luas". Hal ini menyebabkan adanya ketidakjelasan makna dan ketidaktepatan susunan kalimat.

Kata "berinteraksi"pada kalimat (18) memiliki makna hal saling melakukan aksi dan berhubungan pada entri KBBI. Kata "saling"memiliki makna kata untuk menerangkan perbuatan yang berbalas-balasan. Maka pada kata "berinteraksi" tidak diperlukan adanya frasa "satu dengan yang lainnya". Hal tersebut menyebabkan adanya ketidakhematan penggunaan kata dalam suatu kalimat. Dari berbagai bentuk kesalahan tersebut, maka dapat disimpulkan pembenarannya sebagai berikut.

(2) "Sosiologi atau ilmu masyarakat ialah ilmu yang mempelajari struktur dan proses-proses sosial, termasuk perubahan-perubahan sosial".

(6)"berusaha mengenali berbagai persamaan dan perbedaan sampai kepada generalisasi”.

(7) "memberikan uraian tentang variasi bentuk sosial dan mencatat asal-usul serta perkembangan manusia dengan adat-istiadatnya, mencakup dimensi waktu".

(11)“sosiologi merupakan ilmu sosial yang paling luas dasar-dasarnya”.

(18) "Elemen-elemen sosial itu terdiri atas tindakan-tindakan sosial yang dilakukan individu-individu yang berinteraksi"

\section{SIMPULAN}

Dari pembahasan analisis kesalahan kaidah penulisan pada buku teks Sosiologi Kelas X SMA tersebut memiliki 3 jenis kesalahan, yaitu kesalahan penulisan tataran Morfologi, kesalahan penulisan tataran Ejaan Bahasa Indonesia, dan kesalahan penulisan tataran Sintaksis. Pada kesalahan penulisan tataran Morfologi terdapat 1 kesalahan pada penggunaan prefiks me(N), 2 kesalahan penulisan dalam tataran Ejaan Bahasa Indonesia, dan 5 kesalahan penulisan dalam tataran Sintaksis. Karakteristik-karakteristik kalimat efektif meliputi kelugasan, ketepatan, kejelasan, kehematan, dan kesejajaran. Apabila pada suatu kalimat tidak memenuhi syarat tersebut, maka kalimat menjadi tidak efektif dalam tataran sintaksis. 


\section{DAFTAR PUSTAKA}

Abdul Chaer. 2008. Morfologi Bahasa Indonesia (Pendekatan Proses). Jakarta: Rineka Cipta

Anjarsari, N., Suwandi, S., \& Mulyono, S. (2013). Analisis kesalahan pemakaian bahasa Indonesia dalam karangan mahasiswa penutur bahasa asing di Universitas Sebelas Maret.

Angkowo, Kosasih. 2011. Optimalisasi Media Pembelajaran.Jakarta : PT. Grasindo

Ariningsih, N. E., Sumarwati, S., \& Saddhono, K. (2012). Analisis Kesalahan Berbahasa Indonesia dalam Karangan Eksposisi Siswa Sekolah Menengah Atas. BASASTRA, 1(1).

Ayudia, A., Suryanto, E., \& Waluyo, B. Analisis Kesalahan Penggunaan Bahasa Indonesia Dalam Laporan Hasil Observasi Pada Siswa SMP. Jurnal Penelitian Bahasa, Sastra Indonesia, dan Pengajarannya, 4(1), 34-49.

Ervina, Y. (2017). Kesalahan Penggunaan Ejaan Bahasa Indonesia dalam Artikel pada Majalah Dinding di SMA N 2 Solok Selatan (Doctoral dissertation, STKIP PGRI SUMATERA BARAT).

Hasanudin, C. (2017). Analisis Kesalahan Berbahasa Pada Penulisan Media Luar Ruang Di Kabupaten Bojonegoro. Jurnal Pendidikan Bahasa dan Sastra UPI, 17(1), 120-129.

Jati, R. R. (2019). SEMANTICS IN OBEY CLOTHING T-SHIRT DISCOURSE: A STUDY OF SEMANTICS. Apollo Project: Jurnal Ilmiah Program Studi Sastra Inggris, 8(2). https://doi.org/10.34010/apollo.v8i2.2110

Johan, G. M., \& Ghasya, D. A. V. (2017). Analisis kesalahan morfologis dalam proses diskusi siswa sekolah dasar. Visipena Journal, 8(1), 124-134.

Lestari, S. A. (2019). Analisis Kesalahan Ejaan Bahasa Indonesia (Ebi) Dalam Website Detik. Com (Doctoral dissertation).

Nurwicaksono, B. D., \& Amelia, D. (2018). Analisis kesalahan berbahasa Indonesia pada teks ilmiah mahasiswa. AKSIS: Jurnal Pendidikan Bahasa dan Sastra Indonesia, 2(2), 138153.

Pateda, Mansoer. 1989. Analisis Kesalahan. Flores: Penerbit Nusa Indah

Priyono, Y. (2012). Analisis kesalahan berbahasa bidang morfologi pada mading di Universitas Muhammadiyah Surakarta (Doctoral dissertation, Universitas Muhammadiyah Surakarta).

Pusat Perbukuan. 2006. Pedoman Penulisan Buku Pelajaran, Pemetaan tentang Nosi dan Fungsi di dalam Bahasa Indonesia. Jakarta: Departemen Pendidikan Nasional

Rindyana, B. S. B., \& Chandra, T. D. (2012). Analisis kesalahan siswa dalam menyelesaikan soal cerita matematika materi sistem persamaan linear dua variabel berdasarkan analisis Newman (Studi Kasus MAN Malang 2 Batu). Artikel Ilmiah Universitas Negeri Malang, $1(2)$.

Ruswanto. 2009. Sosiologi. Jakarta: Mefi Caraka

Sardila, V. (2016). Strategi Pengembangan Linguistik Terapan Melalui Kemampuan Menulis Biografi dan Autobiografi: Sebuah Upaya Membangun Keterampilan Menulis Kreatif Mahasiswa. An-Nida', 40(2), 110-117.

Sari, D. R. (2019). ANALISIS KESALAHAN PENGGUNAAN EJAAN BAHASA INDONESIA (EBI) PADA KOLOM OPINI SURAT KABAR SERAMBI. Jurnal Samudra Bahasa, 2(1), 25-31.

Setiawan, D. A. (2016). Analisis Kesalahan Sintaksis Bahasa Indonesia dalam Karangan Deskripsi Siswa Kelas VI SDN Kanigoro 02 Kecamatan Pagelaran yang Berbahasa Ibu Bahasa Madura. Pancaran Pendidikan, 5(3), 25-36.

Setyawati, Nanik. 2010. “Analisis Kesalahan Berbahasa Indonesia”. Surakarta: Yuma Pustaka.

Tobing, R. L. (2003). Analisis Kesalahan Sintaksis Bahasa Prancis oleh Pembelajar Berbahasa Indonesia: Sebuah Studi Kasus. Jurnal Humaniora, 15(3), 327-335

Tussolekha, R. (2019). Kesalahan Penggunaan Ejaan Bahasa Indonesia pada Makalah Karya Mahasiswa. AKSARA: Jurnal Bahasa dan Sastra, 20(1). 